Article

\title{
Alphacoronaviruses Detected in French Bats Are Phylogeographically Linked to Coronaviruses of European Bats
}

\author{
Anne Goffard 1,*, Christine Demanche ${ }^{2}$, Laurent Arthur ${ }^{3}$, Claire Pinçon ${ }^{4}$, Johan Michaux ${ }^{5,6}$ \\ and Jean Dubuisson ${ }^{1}$
}

Received: 14 September 2015; Accepted: 23 November 2015; Published: 2 December 2015

Academic Editor: Andrew Mehle

1 Molecular \& Cellular Virology, University Lille, CNRS, Inserm, CHU Lille, Institut Pasteur de Lille, U1019-UMR 8204-CIIL-Centre d'Infection et d'Immunité de Lille, Bâtiment IBL. 1 rue du Pr. Calmette CS 50447, 59021 Lille Cedex, France; jean.dubuisson@ibl.cnrs.fr

2 Bacterial Respiratory Infections: Pertussis and Tuberculosis, University Lille, CNRS, Inserm, CHU Lille, Institut Pasteur de Lille, U1019-UMR 8204-CIIL-Centre d'Infection et d'Immunité de Lille, F-59000 Lille, France; christine.demanche@univ-lille2.fr

3 Museum d'Histoire Naturelle de Bourges, Les Rives d'Auron, allée René Ménard, 18000 Bourges, France; laurent.arthur@ville-bourges.fr

4 University Lille, CHU Lille, EA 2694-Santé publique: épidémiologie et qualité des soins, F-59000 Lille, France; claire.pincon@univ-lille2.fr

5 Conservation Genetics Unit, Institute of Botany (B. 22), University Liège, 4000 Liège, Belgium; johan.michaux@ulg.ac.be

6 CIRAD TA C-22/E-Campus international de Baillarguet, 34398 Montpellier Cedex 5, France

* Correspondence: anne.goffard@univ-lille2.fr; Tel.: +33-3-20-87-11-62; Fax: +33-3-20-87-12-01

\begin{abstract}
Bats are a reservoir for a diverse range of viruses, including coronaviruses (CoVs). To determine the presence of CoVs in French bats, fecal samples were collected between July and August of 2014 from four bat species in seven different locations around the city of Bourges in France. We present for the first time the presence of alpha-CoVs in French Pipistrellus pipistrellus bat species with an estimated prevalence of $4.2 \%$. Based on the analysis of a fragment of the RNA-dependent RNA polymerase $(R d R p)$ gene, phylogenetic analyses show that alpha-CoVs sequences detected in French bats are closely related to other European bat alpha-CoVs. Phylogeographic analyses of $R d R p$ sequences show that several CoVs strains circulate in European bats: (i) old strains detected that have probably diverged a long time ago and are detected in different bat subspecies; (ii) strains detected in Myotis and Pipistrellus bat species that have more recently diverged. Our findings support previous observations describing the complexity of the detected CoVs in bats worldwide.
\end{abstract}

Keywords: bats; alphacoronavirus; coronavirus; phylogeographic analysis; phylogenetic analysis; Europe; molecular characterization

\section{Introduction}

In 2012, a novel coronavirus (CoV), the Middle East Respiratory Syndrome (MERS)-CoV, emerged in humans in the Arabian Peninsula [1]. This CoV is highly pathogenic, as was the Severe Acute Respiratory Syndrome (SARS)-CoV that has emerged in 2002/2003 in China, causing a worldwide outbreak with 774 deaths [2]. CoV belongs to the subfamily of Coronaviridae in the order of Nidovirales. CoVs are divided into four genetic and serologic genera: alpha- and beta-CoVs, that infect mammals, and gamma- and delta-CoVs known to infect mainly birds [3]. 
Bats, in the order of Chiroptera, are widely distributed across various ecosystems. They constitute one of the largest groups of mammals, second in number of species after Rodentia and first in terms of individuals present on Earth [4]. Bats are the only mammals that can fly. They fly to hunt, to change their habitat for hibernation and to migrate. However, less than $3 \%$ of extant bat species show migratory movements greater than $50 \mathrm{~km}$ [5]. The order of Chiroptera is divided into two suborders: Megachiroptera and Microchiroptera [6]. Microchiroptera were reported to live in Europe with 53 species described [6]. European bats inhabit temperate regions and use torpor and hibernation during winter. Chiropters occupy diversified habitats from cities to the countryside and exhibit a large diversity of diets. Their different diets led bats to colonize various ecosystems. In Europe, Microchiroptera are mainly considered as insectivorous. They nest in attics, barns, or unoccupied buildings but also in rocks, trees, barks, hollows, and under leaves [7]. In Europe, bats are often the only wild mammals living in human habitats. Some bat species are solitary but, frequently, they form colonies that can reach a million of individuals. In France, 34 bat species have been described and two species, Pipistrellus pipistrellus and Eptesicus serotinus, are present in the whole territory. Bats have been considered as the natural hosts of many common animal and human viruses, such as measles or mumps, and now they have been considered to be natural reservoirs for SARS-CoV and MERS-CoV (reviewed in [8]).

Phylogeography has been defined as the "field of study concerned with the principles and processes governing the geographical distributions of geographical lineages, especially those within and among closely related species" [9]. The tools of phylogeography have been applied to various fields of biology, such as biodiversity, and recently to explore the links between human migration and viral outbreaks [10]. Thus, using phylogeographic analyses, it has been shown that the HIV outbreak was due to repeated introductions of simian immunodeficiency viruses (SIVs) in the human population [11]. These tools are also used to study the spread of the flu outbreak in 2009 or to speculate on the origin of human hepatitis B $[12,13]$. Therefore, phylogeography proposes a set of tools that can help to understand how $\mathrm{CoV}$ circulate among an animal population, such as uropean bats as described here.

Since 2008, alpha- and beta-CoVs have been identified in several European countries from various bat species, however, no data are available on the presence of CoVs in French bats, as proved by the consultation of the database of bat-associated viruses (http://www.mgc.ac.cn/ DBatVir/) [14-19]. The aim of this study is to describe alpha-CoVs among French bats, especially in Pipistrellus pipistrellus, one of the most common bats in France. To our knowledge, we present the first report of alpha-CoV RNA detection in French bats and the phylogeographic relationships between European alpha-CoVs, based on the analyses of previously published sequences of bat alpha-CoVs.

\section{Materials and Methods}

\subsection{Study Area and Sampling}

Samples were collected from seven distinct locations, each harboring a single bat species, during July and August of 2014. Colonies were located near Bourges in the central region of France (Figure 1). The roosts of bat colonies were mainly human dwellings, such as attics and barns (Table 1). Around 10 to 40 individuals constituted each colony. During the period of collection, males, pregnant and lactating females, as well as young animals born that year inhabited in the same bat colony. The bats species were identified based on their morphologic characteristics according to the European bat identification keys [20].

A total of 162 guano samples were collected from four bat species, Pipistrellus pipistrellus (118 specimens), Barbastella barbastellus (24 specimens), Myotis myotis (10 specimens) and Eptesicus serotinus (10 specimens) (Table 1), as previously described [21,22]. To collect bat guano samples, clean plastic sheets were laid down on flat surfaces beneath bat roosts before sunset. Three days later, fresh guano samples were collected and preserved in $250 \mu \mathrm{L}$ of RNAlater (Applied Biosystems, Courtabœuf, France) during shipment by mail. Several fecal samples were harvested for each colony. On receipt, samples were stored at $-80^{\circ} \mathrm{C}$ until analysis. 
Table 1. Prevalence of alpha-CoV in French bat species.

\begin{tabular}{|c|c|c|c|c|c|c|c|c|c|c|c|c|c|}
\hline \multirow[b]{2}{*}{ Bat Species } & \multirow[b]{2}{*}{$\begin{array}{l}\text { Size of Bat } \\
\text { Colonies * }\end{array}$} & \multirow[b]{2}{*}{ Day Roost } & \multicolumn{7}{|c|}{$\begin{array}{l}\text { Positive Samples/Total of } \\
\text { Tested Samples by Location }\end{array}$} & \multirow{2}{*}{$\begin{array}{c}\begin{array}{c}\text { Total of Positive } \\
\text { Samples/Total of } \\
\text { Tested Samples }\end{array} \\
\text { All Areas }\end{array}$} & \multirow[t]{2}{*}{$\begin{array}{c}\% \text { of } \\
\text { Positive }\end{array}$} & \multirow[t]{2}{*}{ Sequences } & \multirow[t]{2}{*}{$\begin{array}{l}\text { Coronavirus } \\
\text { Group }\end{array}$} \\
\hline & & & 1 & 2 & 3 & 4 & 5 & 6 & 7 & & & & \\
\hline $\begin{array}{l}\text { Pipistrellus } \\
\text { pipistrellus }\end{array}$ & $\begin{array}{l}\text { Small and } \\
\text { Medium }\end{array}$ & Attics, Barns & $3 / 53$ & $2 / 20$ & $0 / 10$ & $0 / 35$ & & & & $5 / 118$ & 4.2 & $\begin{array}{l}\text { Ppip1_FR_2014, } \\
\text { Ppip2_FR_2014, } \\
\text { Ppip3_FR_2014 }\end{array}$ & $\alpha$ \\
\hline $\begin{array}{c}\text { Barbastella } \\
\text { barbastellus }\end{array}$ & Small & Attic & & & & & & & $0 / 24$ & & 0 & & \\
\hline $\begin{array}{l}\text { Myotis } \\
\text { myotis }\end{array}$ & Small & Barn & & & & & $0 / 10$ & & & & 0 & & \\
\hline $\begin{array}{l}\text { Eptesicus } \\
\text { serotinus }\end{array}$ & Small & Attic & & & & & & $0 / 10$ & & & 0 & & \\
\hline Total & & & & & & & & & & $5 / 162$ & 3.1 & & \\
\hline
\end{tabular}

* Bat colony size was scored as follows: small, 10 to 30 individuals; medium, 31 to 200 individuals; large, >200 individuals. 


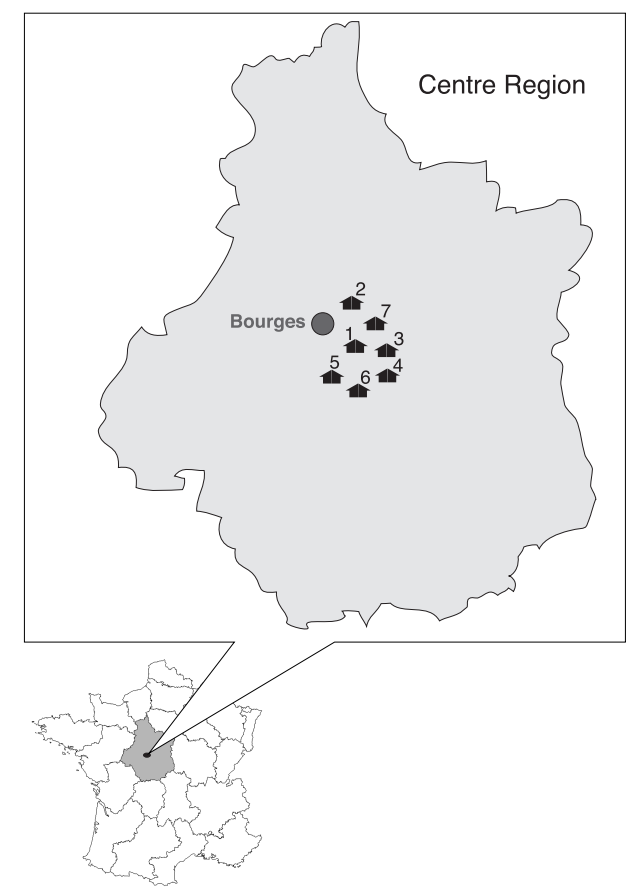

Figure 1. Geographical locations of bat colonies where guano samples were taken during the summer of 2014. The colonies are numbered 1 to 7 and georeferenced as: $1\left(02^{\circ} 34^{\prime} 54^{\prime \prime} \mathrm{E} ; 47^{\circ} 00^{\prime} 39^{\prime \prime} \mathrm{N}\right)$, $2\left(02^{\circ} 31^{\prime} 02^{\prime \prime} \mathrm{E} ; 47^{\circ} 04^{\prime} 59^{\prime \prime} \mathrm{N}\right), 3\left(02^{\circ} 32^{\prime} 19^{\prime \prime} \mathrm{E} ; 46^{\circ} 56^{\prime} 23^{\prime \prime} \mathrm{N}\right), 4\left(02^{\circ} 33^{\prime} 38^{\prime \prime} \mathrm{E} ; 47^{\circ} 02^{\prime} 39^{\prime \prime} \mathrm{N}\right), 5\left(02^{\circ} 31^{\prime} 22^{\prime \prime}\right.$ E; $\left.47^{\circ} 04^{\prime} 24^{\prime \prime} \mathrm{N}\right), 6\left(02^{\circ} 18^{\prime} 59^{\prime \prime} \mathrm{E} ; 46^{\circ} 51^{\prime} 27^{\prime \prime} \mathrm{N}\right)$, and $7\left(02^{\circ} 23^{\prime} 21^{\prime \prime} \mathrm{E}, 46^{\circ} 49^{\prime} 28^{\prime \prime} \mathrm{N}\right)$. They are scattered around the city of Bourges, in the central region of France.

\subsection{Genome Detection and Sequencing}

Fecal pellets stored in RNAlater were tested after mechanical lysis using a MagNAlyser (Roche Diagnostics, Meylan, France) according to the manufacturer's instructions. Viral RNA was extracted from $100 \mu \mathrm{L}$ of fecal homogenate using a viral RNA mini kit and eluted in $50 \mu \mathrm{L}$ of elution buffer (Qiagen, Courtabœuf, France). Samples were then analyzed for the presence of CoV RNA using a nested reverse transcription (RT)-PCR targeting the RNA-dependent RNA polymerase $(R d R p)$, slightly modified from Souza et al. [23]. RNA $(5 \mu \mathrm{L})$ was random primed reverse transcribed (High Capacity cDNA Reverse Transcription kit; Applied Biosystems). Twenty-five microliters of reactions were carried out using Taq DNA polymerase (New England Biolabs, Evry, France) with $2 \mu \mathrm{M}$ of sense and anti-sense primer, and $5 \mu \mathrm{L}$ of complementary DNA (cDNA). Thermal cycling was set at $94{ }^{\circ} \mathrm{C}$ for $1 \mathrm{~min}$ and then 40 cycles of $94{ }^{\circ} \mathrm{C}$ for $30 \mathrm{~s}, 50{ }^{\circ} \mathrm{C}$ for $30 \mathrm{~s}, 68^{\circ} \mathrm{C}$ for $40 \mathrm{~s}$, and final extension at $68{ }^{\circ} \mathrm{C}$ for $5 \mathrm{~min}$. The nested PCR protocol, unmodified from Souza et al. [23], used $1 \mu \mathrm{L}$ of first round PCR product. Negative and positive controls were included in each experiment, in DNA extraction, reverse transcription, DNA PCR, and nested PCR amplifications. Amplicons were purified using the NucleoSpin Gel and PCR clean-up kit (Macherey-Nagel, Hoerdt, France). Purified products were cloned using TOPO TA cloning kit for subcloning with TOP10F' E. coli (Life Technologies, Illkirch, France). Three positive clones of each amplicon were sent for sequencing using M13 forward and reverse primers to Genoscreen (Pasteur Campus, Genopole of Lille, Lille, France).

\subsection{Sequence Analysis}

The $R d R p$ gene sequences described in this study were initially aligned with homologous sequences of alpha-CoVs from humans, civet, camel, and bats (Table 2) using CLUSTAL X v1.63b [24]. The aligned sequences were converted to distance matrix (\% of differences) using PAUP 4.0b10 software [25]. Maximum likelihood (ML) analyses of sequences were carried out with PhyML 
v3.0 [26] using the GTR (general time reversible) $+\Gamma$ (gamma distribution of rates with four rate categories) + I (proportion of invariant sites) model. The appropriate model of sequence evolution was selected using PhyML with automatic model selection by Smart Model Selection (SMS) to determine the evolutionary model which best fits the input data [27]. Evaluation of statistical confidence in nodes was based on 1000 bootstrap replicates [28]. Alignments of polymerase gene sequences used in the various analyses are available upon request from the corresponding author.

\subsection{Phylogeographic Analysis}

A minimum spanning network was constructed using the MINSPNET algorithm available in the ARLEQUIN 2.0 program [29]. The genetic divergences between sample groups were estimated using a distance analysis $\left(\mathrm{K}_{2} \mathrm{P}\right.$, mega program).

Table 2. List of sequences used for phylogeny analyses with Genbank accession number, coronavirus group, host species and geographic origin and name used in this study.

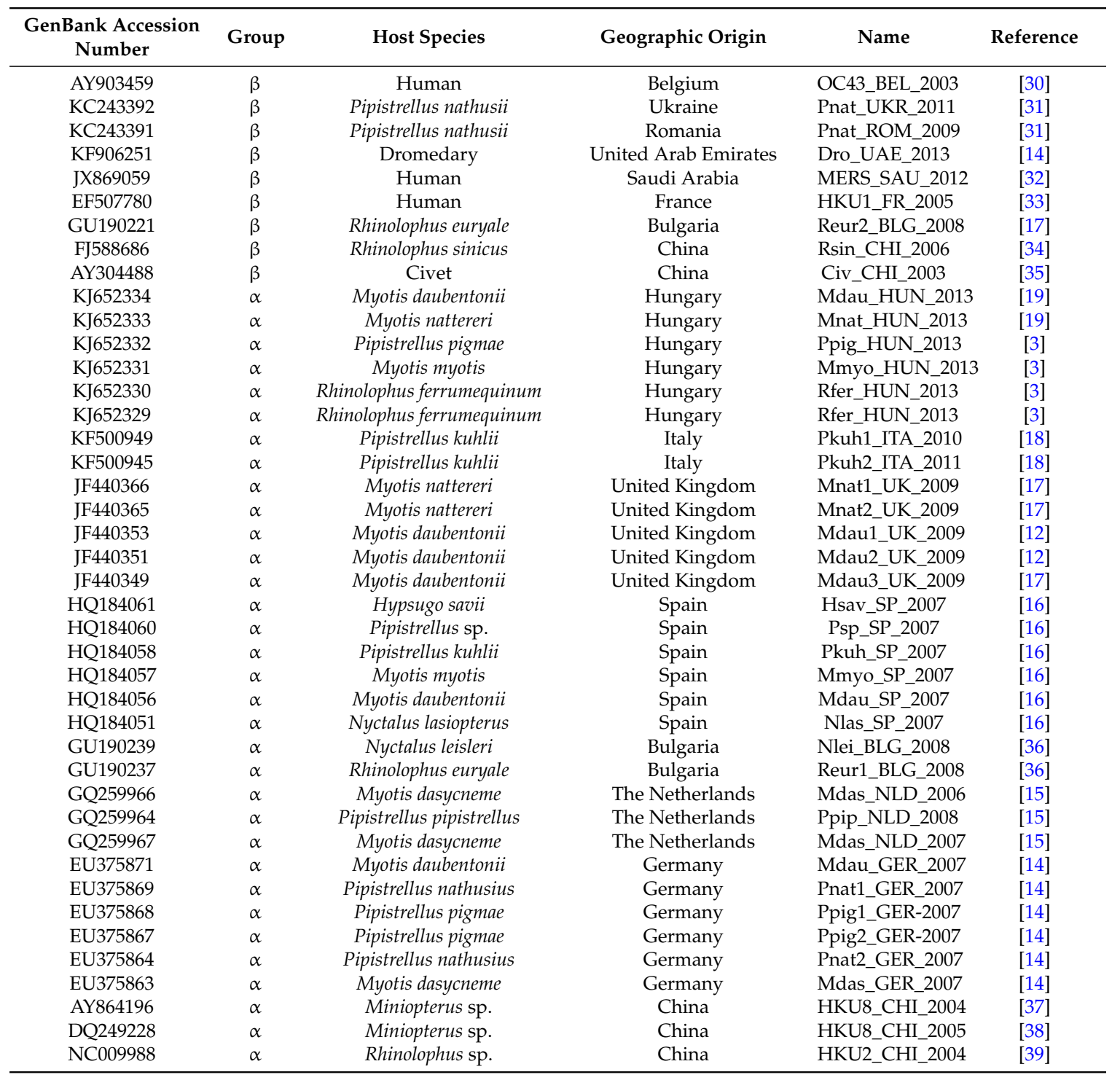

\subsection{Statistical Analyses}

Prevalences of $\mathrm{CoV}$ were estimated with $95 \%$ confidence intervals constructed using the normal approximation. A Fisher' exact test was done to compare the prevalence of $\mathrm{CoV}$ for Pipistrellus 
pipistrellus to the prevalence for the other species (the other species were considered as a single group since no positive sample had been detected).

\subsection{Nucleotide Sequence Accession Numbers}

$R d R p$ gene sequences were deposited in GenBank under accession number KT345294 to KT345296.

\section{Results}

A total of 162 guano samples of bats were collected from seven bat colonies located at seven different sites around the city of Bourges in the central region of France, during the summer of 2014 (Figure 1). Guano collections were all carried out in July, except for colony 7, which was completed in August.

CoV RNA was detected in five out of 162 samples. All the CoV-positive samples were detected from Pipistrellus pipistrellus. No CoV RNA was detected from Barbastella barbastellus, Myotis myotis and Eptesicus serotinus. Prevalence of $\mathrm{CoV}$ was estimated at 3.1\% (CI95\%: $(0.4 \% ; 5.8 \%)$ ) in the whole sample, all positive sample being detected in Pipistrellus pipistrellus, leading to a prevalence for this species estimated at $4.2 \%$ (C195\% : $(0.6 \% ; 7.9 \%))$, compared to $0 \%$ for the other species; however, this difference in prevalence was not significant (Fisher' exact test, $p=0.32$ ).

To characterize the overall diversity of $\mathrm{CoV}$ sequences, a phylogenetic analysis of bat CoVs was performed using the sequences of a 440 base pairs (bps) PCR amplicon of the RdRp gene from three positive samples. Two sequences, Ppip1_FR_2014 and Ppip2_FR_2014, were obtained from guano collected in a same bat colony. The third French sequence, Ppip3_FR_2014, was obtained from guano collected from another bat colony located $12 \mathrm{~km}$ from the first site. For the two remaining samples, we were not able to obtain the sequence of the fragment. Nucleotide sequence analysis shows that the bat $\mathrm{CoV}$ corresponding to the sequences amplified from French bats belong to alpha-CoV genera (Figure 2). Comparison of the RdRp-aligned sequences was carried out on 277 positions, including gaps, for a total of 48 taxa: three original sequences and 45 previously published (Table 2). The beta-CoV and alpha-CoV sequences are clearly separated in two groups supported each by $100 \%$ bootstrap value (Figure 2). Our analyses showed that genetic divergence between beta- and alpha-CoV sequences is up to $35 \%$.

Among the alpha-CoV group, sequences appear separated in two lineages: 1 and 2 (Figure 2). Nucleotide divergence between groups 1 and 2 varies from $22.02 \%$ to $30 \%$ (Figure S1). We also noticed that sequences of alpha-CoV are grouped according to the host species and independently of date or of the sampling location.

Thus, lineage 1 includes several groups of sequences: (i) HKU8 sequences obtained from Miniopterus sp. in 2004 and 2013 in China are grouped with the $72.1 \%$ bootstrap value; (ii) another group includes sequences obtained from P. kuhli in 2007 in Spain, and in 2010 in Italy $(99 \%$ of bootstrap values); and (iii) both French sequences from Pipistrellus pipistrellus, Ppip1_FR_2014 and Ppip2_FR_2014, are closely related to each other (2.90\% of nucleotide sequence divergence) and grouped with sequences obtained from P. pipistrellus in the Netherlands in 2008 and P. kuhli in Italy in 2010 with a $99.4 \%$ bootstrap value. Other sequences belong to lineage 1 , such as sequences obtained from R. ferrumequinum in 2013 in Hungary, from N. leisleri in 2008 in Bulgaria, from M. myotis, N. lasiopterus, and H. savii in Spain in 2007.

Lineage 2 includes several groups. The first one includes sequences obtained from M. nattereri in 2009 and 2013 in the United Kingdom and Hungary (71.5\% bootstrap value); the second one associates sequences obtained from M. daubentonii between 2007 and 2013 in several countries ( $92.1 \%$ bootstrap value); the third one corresponds to sequences from P. pigmae in 2007 in Germany and in 2013 in Hungary (73.6\% bootstrap value); and the fourth one includes sequences from P. nathusius in 2007 in Germany (95.6\% bootstrap value). Sequences obtained from M. dasycneme in 2006 in the Netherlands, and in 2007 in Germany and the Netherlands, are also grouped with low 
support (bootstrap values smaller than 60\%). A French bat sequence obtained from P. pipistrellus, Ppip3_FR_2014, also belongs to this last group. Finally, sequences obtained from M. myotis in 2013 in Hungary and from Pipistrellus sp. in 2007 in Spain are also included in lineage 2.

Finally, two sequences obtained from Rhinolophus sp. in 2004 in China and from R. Euryale in 2008 in Bulgaria appear highly separated in a divergent lineage, supported by an $85.2 \%$ bootstrap value.

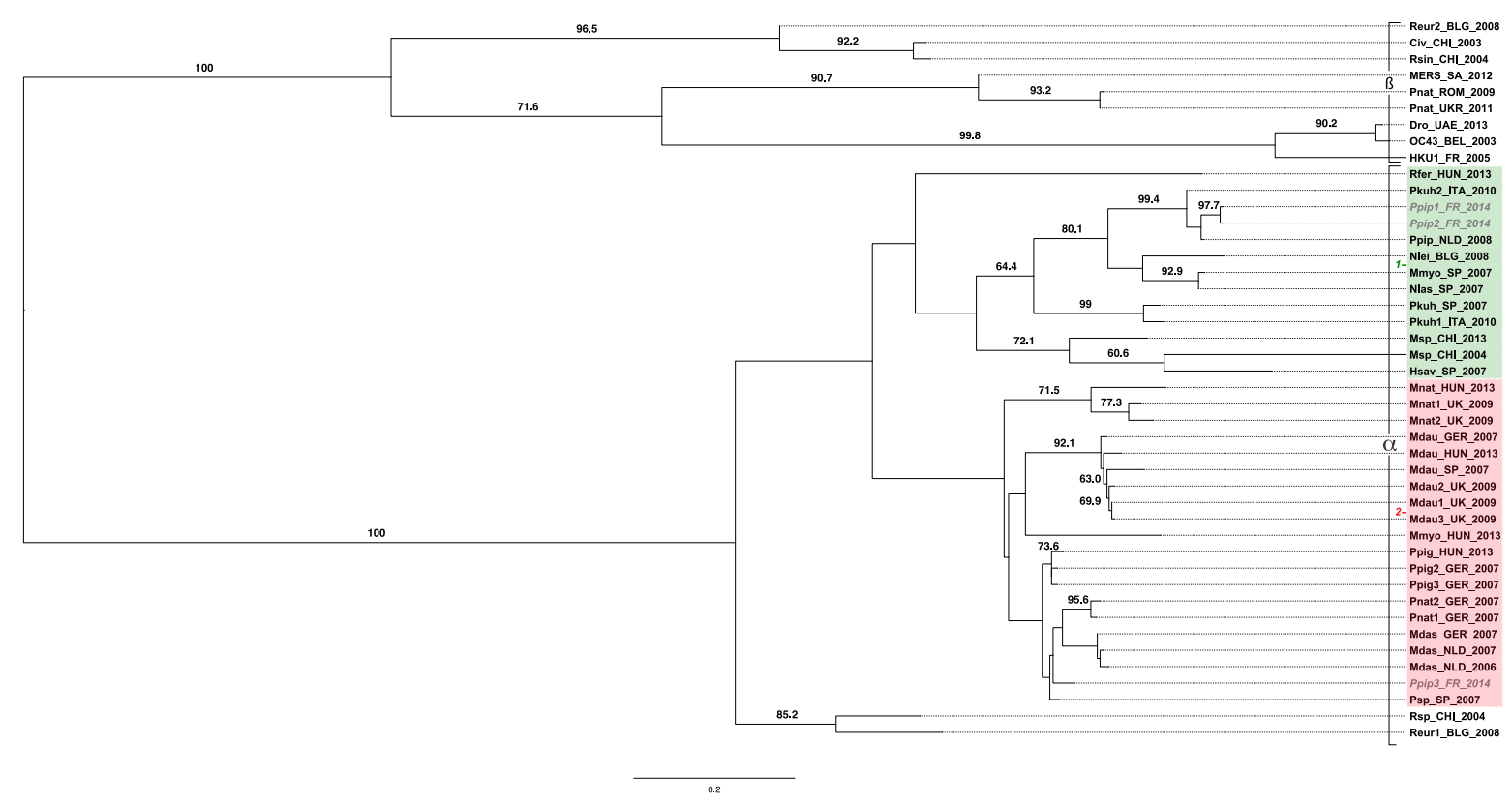

Figure 2. Phylogenetic tree of the partial RNA-dependent RNA polymerase ( $R d R p$ ) gene (277 bp) of coronavirus strains found in bats. The phylogram results from bootstrapped data sets obtained using PhyML 3.0 program [26]. The tree was visualized using the FigTree program, version 1.4.2. The percentages above the branches are the frequencies with which a given branch appeared in 1000 bootstrap replications. Bootstrap values below $60 \%$ are not displayed. Taxa are named according to the following pattern: bat species/country of origin/year of detection. Sequences belonging to lineage 1 are presented in the green box, those belonging to lineage 2 in the red box. French bat sequences are presented in grey.

The minimum spanning network illustrates the mutational relationship of the European alpha-CoVs in bats (Figure 3). Thirty-four different alpha-CoV sequences were used for analyses and evidenced several groups. The first group (group I) associates three sequences, closely interconnected with two and five mutational steps obtained from M. dasycneme in 2007 in Germany and in 2006 and 2007 in the Netherlands, and seven sequences obtained from several subspecies of Pipistrellus in various countries. The French sequence Ppip3_FR_2014, detected from Pipistrellus guano, belongs to this group.

Two other groups (groups II and III) are separated from group I with 30 mutational steps each. Group II includes three sequences obtained from M. natttereri in 2009 and 2013 in the United Kingdom and Hungary. Group III includes six sequences obtained from $M$. daubentonii in several countries.

The other analyzed sequences appear highly differentiated with important levels of mutational steps among them (from 34 to 62). An exception is nevertheless observed for the sequences Pkuh2_ITA_2010, Ppip_NLD_2008, Ppip1_FR_2014, Ppip2_FR_2014, Nlas_SP_2007, and Mmyo_SP_2007, which appear more closely related with less than eight mutational steps among them.

The topology of the minimal spanning network adopts the same configuration than the phylogenetic tree. Indeed, lineage 2 observed on the tree is characterized by short branches lengths 
suggesting a recent diversification for these sequences. They also appear closely interconnected in the network, with low levels of mutational steps among them.

In contrast, lineage 1 of the phylogenetic tree is characterized by longer branches lengths, suggesting ancient separations among sequences of this lineage. Important levels of genetic divergence observed between these sequences corroborate this result.

Phylogeographic and phylogenetic analyses therefore give congruent results, although the minimum spanning network sometimes give a better robustness for some groups, represented by lower bootstrap values in the phylogenetic tree.

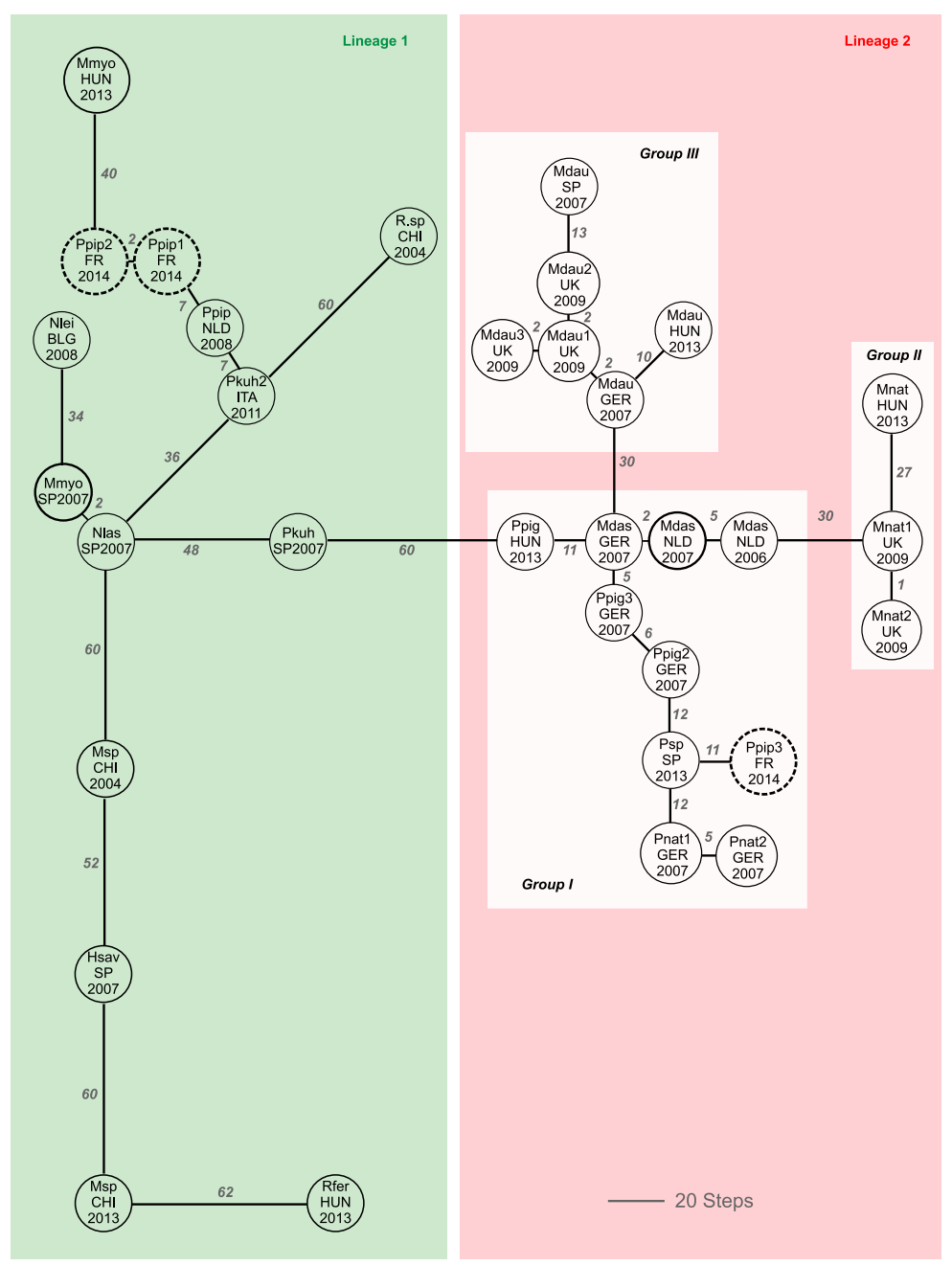

Figure 3. Minimum spanning network constructed using $R d R p$ gene sequences of bat alpha-CoV. Bat species and subspecies, geographic origins and year of detection are indicated. Numbers correspond to the mutational steps observed between sequences. Sequences belonging to lineage 1 are presented in the green box, those belonging to lineage 2 in the red box. Among lineage 2, groups I-III are presented in white boxes. French bat sequences are presented in dotted bold circles.

\section{Discussion}

\subsection{Prevalence of Alpha-CoV in French Pipistrellus pipistrellus}

Previous studies using nested RT-PCR reported important differences in prevalence between bat species in several countries. In China, prevalence of CoV RNA in bats varies between $6.5 \%$ and $48 \%$ [38-40]. In Germany, overall prevalence of alpha- and beta-CoVs was reported at 9.8\% in different bat species [14]. Concerning the prevalence of alpha-CoV in Europe, it reached $75 \%$ in 
Myotis nattereri [14,17]. CoVs are also detected in Barbastella barbastellus, in Myotis myotis, and Eptesicus serotinus species in Europe [17,19,41].

The overall prevalence $(3.1 \%$ (C195\%: $(0.4 \% ; 5.8 \%)$ ) of alpha-CoV reported here in four bat species, and especially in Pipistrellus pipistrellus (4.2\% (CI95\%: $(0.6 \% ; 7.9 \%)$ ) is lower than in previous observations, but is similar to those reported in Pipistrellus sp. in Spain (3.6\%) [16]. The differences can be explained by the way the bat guano was collected. Indeed, in previously published studies, animals were caught to obtain biological samples while, in our work, we collected the fresh guano in different bat colonies. We cannot exclude that we may have studied several samples produced by the same individual. Therefore, our results may potentially be explained by the degradation of viral RNA under natural conditions. In our study, no CoVs were detected in Barbastella barbastellus, Myotis myotis and Eptesicus serotinus species. In addition to the potential degradation of viral RNA, our results may be explained by the low number of collected samples, the small number of bat species sampled, regarding the 34 bat species listed in France, and the sampling location being limited to the area near Bourges. To further extend this study, it will be necessary to analyze a larger number of samples, collected in different locations in France, to determine the real prevalence of $\mathrm{CoV}$ in French bats.

In humans, alpha-CoV, HCoV-229E, and HCoV-NL63, cause the common cold. Bats are identified as natural reservoir for $\mathrm{CoV}$ and, recently, it has been shown that hipposiderid (Hipposideridae) bats may be infected with an alpha-CoV closely related to HCoV-229E [42]. However, in our work, phylogenetic analyses with human alpha-CoV sequences, such as HCoV-229E or HCoV-NL63, failed because the genetic divergences were very high (data not shown).

The phylogenetic analyses conducted from a fragment of $R d R p$ gene reported here show that alpha-CoV sequences are separated into two major lineages, 1 and 2, and a minor group. The genetic divergence between the two major lineages varies between $20 \%$ and $35 \%$. The French sequences are distributed within the two major lineages. Both Ppip1_FR_2014 and Ppip2_FR_2014 sequences detected from guano collected from the same bat colony were closely related, and are included in lineage 1. The third French sequence, Ppip3_FR_2014, obtained from guano collected from another bat colony is included in lineage 2. Both colonies are located by $12 \mathrm{~km}$ away from each other. Such result would be explained by the fact that Pipistrellus bats are very loyal solitary and that they usually remain confined to their own colonies, even if another colony is located $10 \mathrm{~km}$ away. Similar observations have been reported for P. nathusius in Germany or M. nattereri in the United Kingdom [14,17]. Thus, the phylogenetic tree presented here shows several clusters of sequences grouped by bat species. These results confirm the existence of coronavirus strains specific to bat species and suggest a low circulation of viral strains among bat species [14,15,17].

On the basis of genetic diversity, seven lineages of alpha-CoV have been previously described in Europe $[14,15,17]$. The previously described lineages, $1-4$, are distributed among lineage 2, which we have defined. The genetic diversity among alpha-CoV sequences obtained from bats was very high (up to $45.5 \%$ ). Our results show that sequences obtained from several bat species in different European countries are grouped together. A new definition of bat coronavirus lineage seems to be required to describe the diversity of alpha-CoV in Europe.

\subsection{Phylogeographic Relatedness among Alpha-CoVs Detected in European Bats}

Phylogeography is used to study the circulation of an infectious agent and an animal population or the dissemination of an infectious agent in a group of humans [43,44]. Here we used this tool to describe the circulation of alpha- $\mathrm{CoV}$ among European bats. The topology of the minimum spanning network shows that two types of alpha-CoVs strains circulate in European bats. On the one hand, the old strains diverged a long time ago from a common unknown ancestor, as suggested by the large mutational steps observed between sequences belonging to lineage 1 . The identification of the common ancestor of alpha-CoVs strains may be difficult since the diversification of European bats and perhaps bat viruses date to the glacial periods [45]. On the other hand, the strains detected in Myotis and Pipistrellus bat species, which are interconnected with smaller mutational steps, have more 
recently diverged. These strains may have been recently introduced in the European bat populations and have quickly circulated within Myotis and Pipistrellus bat species. This recent introduction may explain why these strains are specific to their host as suggested by previous studies $[15,16]$.

In conclusion, previous studies showed the presence of alpha-CoV in various European bat species. However, to our knowledge, this is the first report describing the presence of alpha-CoV RNA in French bat species, and the first description of phylogeographic relatedness among alpha-CoV detected in European bats. Our findings support previous observations describing the complexity of the detected CoVs in bats in Europe, but also in South America, China, and Eastern Thailand $[40,46,47]$.

Acknowledgments: We thank René Courcol, which allowed us to use the facilities of molecular biology platform of the Microbiology Institute of the Biology Pathology Centre of University Hospital of Lille. We are grateful to Anny Dewilde for providing the CoV positive sample as control of pan-coronavirus RT-PCR development. We thank especially Cécile-Marie Aliouat and Annie Standaert who facilitate the contacts between collaborators.

Author Contributions: Collection of bat guano: L.A. Conceived, designed and performed experiments: A.G. Analyzed the data: A.G., C.D., J.M. and J.D. Wrote the paper: A.G., C.D., J.M. and J.D.

Conflicts of Interest: The authors declare no conflict of interest.

\section{References}

1. Zaki, A.M.; van Boheemen, S.; Bestebroer, T.M.; Osterhaus, A.D.M.E.; Fouchier, R.A.M. Isolation of a Novel Coronavirus from a Man with Pneumonia in Saudi Arabia. N. Engl. J. Med. 2012, 367, 1814-1820. [CrossRef] [PubMed]

2. Peiris, J.S.M.; Guan, Y.; Yuen, K.Y. Severe acute respiratory syndrome. Nat. Med. 2004, 10, S88-S97. [CrossRef] [PubMed]

3. Woo, P.C.Y.; Lau, S.K.P.; Lam, C.S.F.; Lau, C.C.Y.; Tsang, A.K.L.; Lau, J.H.N.; Bai, R.; Teng, J.L.L.; Tsang, C.C.C.; Wang, M.; et al. Discovery of seven novel Mammalian and avian coronaviruses in the genus deltacoronavirus supports bat coronaviruses as the gene source of alphacoronavirus and betacoronavirus and avian coronaviruses as the gene source of gammacoronavirus and deltacoronavirus. J. Virol. 2012, 86, 3995-4008. [PubMed]

4. Jones, K.E.; Purvis, A.; MacLarnon, A.; Bininda-Emonds, O.R.P.; Simmons, N.B. A phylogenetic supertree of the bats (Mammalia: Chiroptera). Biol. Rev. Camb. Philos. Soc. 2002, 77, 223-259. [CrossRef] [PubMed]

5. Bisson, I.-A.; Safi, K.; Holland, R.A. Evidence for Repeated Independent Evolution of Migration in the Largest Family of Bats. PLoS ONE 2009, 4, e7504. [CrossRef] [PubMed]

6. Protected Bat Species UNEP/EUROBATS. Available online: http://www.eurobats.org/about_eurobats/ protected_bat_species (accessed on 15 July 2015).

7. Brunet-Rossinni, A.K.; Austad, S.N. Ageing studies on bats: A review. Biogerontology 2004, 5, $211-222$. [CrossRef] [PubMed]

8. Han, H.-J.; Wen, H.-L.; Zhou, C.-M.; Chen, F.-F.; Luo, L.-M.; Liu, J.-W.; Yu, X.-J. Bats as reservoirs of severe emerging infectious diseases. Virus Res. 2015, 205, 1-6. [CrossRef] [PubMed]

9. Avise, J.C. Phylogeography: The History and Formation of Species; Harvard University Press: Cambridge, MA, USA, 2000.

10. Bloomquist, E.W.; Lemey, P.; Suchard, M.A. Three roads diverged? Routes to phylogeographic inference. Trends Ecol. Evol. 2010, 25, 626-632. [CrossRef] [PubMed]

11. Hahn, B.H.; Shaw, G.M.; de Cock, K.M.; Sharp, P.M. AIDS as a zoonosis: Scientific and public health implications. Science 2000, 287, 607-614. [CrossRef] [PubMed]

12. Nelson, M.I.; Tan, Y.; Ghedin, E.; Wentworth, D.E.; st George, K.; Edelman, L.; Beck, E.T.; Fan, J.; Lam, T.T.-Y.; Kumar, S.; et al. Phylogeography of the spring and fall waves of the H1N1/09 pandemic influenza virus in the United States. J. Virol. 2011, 85, 828-834. [CrossRef] [PubMed]

13. Souza, B.F.; de Carvalho-Dominguez-Souza, B.F.; Drexler, J.F.; Lima, R.S.; de Rosário, M.; de Oliveira-Hughes-Veiga-do-Rosário, M.; Netto, E.M. Theories about evolutionary origins of human hepatitis B virus in primates and humans. Braz. J. Infect. Dis. Off. Publ. Braz. Soc. Infect. Dis. 2014, $18,535-543$. 
14. Gloza-Rausch, F.; Ipsen, A.; Seebens, A.; Göttsche, M.; Panning, M.; Drexler, J.F.; Petersen, N.; Annan, A.; Grywna, K.; Müller, M.; et al. Detection and prevalence patterns of group I coronaviruses in bats, northern Germany. Emerg. Infect. Dis. 2008, 14, 626-631. [CrossRef] [PubMed]

15. Reusken, C.B.E.M.; Lina, P.H.C.; Pielaat, A.; de Vries, A.; Dam-Deisz, C.; Adema, J.; Drexler, J.F.; Drosten, C.; Kooi, E.A. Circulation of group 2 coronaviruses in a bat species common to urban areas in Western Europe. Vector Borne Zoonotic Dis. 2010, 10, 785-791. [CrossRef] [PubMed]

16. Falcón, A.; Vázquez-Morón, S.; Casas, I.; Aznar, C.; Ruiz, G.; Pozo, F.; Perez-Breña, P.; Juste, J.; Ibáñez, C.; Garin, I.; et al. Detection of alpha and betacoronaviruses in multiple Iberian bat species. Arch. Virol. 2011, 156, 1883-1890. [CrossRef] [PubMed]

17. August, T.A.; Mathews, F.; Nunn, M.A. Alphacoronavirus detected in bats in the United Kingdom. Vector Borne Zoonotic Dis. 2012, 12, 530-533. [CrossRef] [PubMed]

18. Lelli, D.; Papetti, A.; Sabelli, C.; Rosti, E.; Moreno, A.; Boniotti, M.B. Detection of coronaviruses in bats of various species in Italy. Viruses 2013, 5, 2679-2689. [CrossRef] [PubMed]

19. Kemenesi, G.; Dallos, B.; Görföl, T.; Boldogh, S.; Estók, P.; Kurucz, K.; Kutas, A.; Földes, F.; Oldal, M.; Németh, V.; et al. Molecular survey of RNA viruses in Hungarian bats: Discovering novel astroviruses, coronaviruses, and caliciviruses. Vector Borne Zoonotic Dis. 2014, 14, 846-855. [CrossRef] [PubMed]

20. Dietz, C.; von Helversen, O. Available online: http://scholar.google.fr/scholar_url?url=http://www.resear chgate.net/profile/Christian_Dietz/publication/274838308_llustrated_Identification_key_to_the_Bats_of_ Europe_-_complete_pdf/links/552b56a60cf2779ab7930be7.pdf\&hl=fr\&sa=X\&scisig=AAGBfm1eq39Y0IQQ R7Pv_3ffuC7mRbBiWw\&nossl=1\&oi=scholarr\&ved=0CB4QgAMoADAAahUKEwj_84DXjPzIAhXH1hQK HWHaBkU (accessed on 6 November 2015).

21. Li, L.; Victoria, J.G.; Wang, C.; Jones, M.; Fellers, G.M.; Kunz, T.H.; Delwart, E. Bat Guano Virome: Predominance of Dietary Viruses from Insects and Plants plus Novel Mammalian Viruses. J. Virol. 2010, 84, 6955-6965. [CrossRef] [PubMed]

22. Ge, X.; Li, Y.; Yang, X.; Zhang, H.; Zhou, P.; Zhang, Y.; Shi, Z. Metagenomic Analysis of Viruses from Bat Fecal Samples Reveals Many Novel Viruses in Insectivorous Bats in China. J. Virol. 2012, 86, 4620-4630. [CrossRef] [PubMed]

23. De Souza Luna, L.K.; Heiser, V.; Regamey, N.; Panning, M.; Drexler, J.F.; Mulangu, S.; Poon, L.; Baumgarte, S.; Haijema, B.J.; Kaiser, L.; et al. Generic detection of coronaviruses and differentiation at the prototype strain level by reverse transcription-PCR and nonfluorescent low-density microarray. J. Clin. Microbiol. 2007, 45, 1049-1052. [CrossRef] [PubMed]

24. Thompson, J.D.; Gibson, T.J.; Plewniak, F.; Jeanmougin, F.; Higgins, D.G. The CLUSTAL_X windows interface: Flexible strategies for multiple sequence alignment aided by quality analysis tools. Nucleic Acids Res. 1997, 25, 4876-4882. [CrossRef] [PubMed]

25. PAUP*: Phylogenetic Analysis Using Parsimony (and Other Methods) 4.0 Beta. Available online: http:/ / www.sinauer.com/paup-phylogenetic-analysis-using-parsimony-and-other-methods-4-0-beta.html (accessed on 15 July 2015).

26. Guindon, S.; Dufayard, J.-F.; Lefort, V.; Anisimova, M.; Hordijk, W.; Gascuel, O. New algorithms and methods to estimate maximum-likelihood phylogenies: Assessing the performance of PhyML 3.0. Syst. Biol. 2010, 59, 307-321. [CrossRef] [PubMed]

27. ATGC: SMS. Available online: http://www.atgc-montpellier.fr/sms/ (accessed on 15 July 2015).

28. Felsenstein, J. Confidence Limits on Phylogenies: An Approach Using the Bootstrap. Evolution 1985, 39, 783-791. [CrossRef]

29. Schneider, S.; Roessli, D.; Excoffier, L. Arlequin: A Software for Population Genetics Data Analysis, 2000th ed.; User Manual Ver 2.000; University of Geneva: Geneva, Switzerland, 2000.

30. Vijgen, L.; Keyaerts, E.; Lemey, P.; Moës, E.; Li, S.; Vandamme, A.-M.; van Ranst, M. Circulation of genetically distinct contemporary human coronavirus OC43 strains. Virology 2005, 337, 85-92. [CrossRef] [PubMed]

31. Annan, A.; Baldwin, H.J.; Corman, V.M.; Klose, S.M.; Owusu, M.; Nkrumah, E.E.; Badu, E.K.; Anti, P.; Agbenyega, O.; Meyer, B.; et al. Human Betacoronavirus 2c EMC/2012-related Viruses in Bats, Ghana and Europe. Emerg. Infect. Dis. 2013, 19, 456-459. [CrossRef] [PubMed] 
32. Van Boheemen, S.; de Graaf, M.; Lauber, C.; Bestebroer, T.M.; Raj, V.S.; Zaki, A.M.; Osterhaus, A.D.M.E.; Haagmans, B.L.; Gorbalenya, A.E.; Snijder, E.J.; et al. Genomic Characterization of a Newly Discovered Coronavirus Associated with Acute Respiratory Distress Syndrome in Humans. mBio 2012, 3, e00473-12. [CrossRef] [PubMed]

33. Vabret, A.; Dina, J.; Gouarin, S.; Petitjean, J.; Tripey, V.; Brouard, J.; Freymuth, F. Human (non-severe acute respiratory syndrome) coronavirus infections in hospitalised children in France. J. Paediatr. Child Health 2008, 44, 176-181. [CrossRef] [PubMed]

34. Yuan, J.; Hon, C.-C.; Li, Y.; Wang, D.; Xu, G.; Zhang, H.; Zhou, P.; Poon, L.L.M.; Lam, T.T.-Y.; Leung, F.C.-C.; et al. Intraspecies diversity of SARS-like coronaviruses in Rhinolophus sinicus and its implications for the origin of SARS coronaviruses in humans. J. Gen. Virol. 2010, 91, 1058-1062. [CrossRef] [PubMed]

35. Guan, Y.; Zheng, B.J.; He, Y.Q.; Liu, X.L.; Zhuang, Z.X.; Cheung, C.L.; Luo, S.W.; Li, P.H.; Zhang, L.J.; Guan, Y.J.; et al. Isolation and characterization of viruses related to the SARS coronavirus from animals in southern China. Science 2003, 302, 276-278. [CrossRef] [PubMed]

36. Drexler, J.F.; Gloza-Rausch, F.; Glende, J.; Corman, V.M.; Muth, D.; Goettsche, M.; Seebens, A.; Niedrig, M.; Pfefferle, S.; Yordanov, S.; et al. Genomic Characterization of Severe Acute Respiratory Syndrome-Related Coronavirus in European Bats and Classification of Coronaviruses Based on Partial RNA-Dependent RNA Polymerase Gene Sequences. J. Virol. 2010, 84, 11336-11349. [CrossRef] [PubMed]

37. Poon, L.L.M.; Chu, D.K.W.; Chan, K.H.; Wong, O.K.; Ellis, T.M.; Leung, Y.H.C.; Lau, S.K.P.; Woo, P.C.Y.; Suen, K.Y.; Yuen, K.Y.; et al. Identification of a novel coronavirus in bats. J. Virol. 2005, 79, 2001-2009. [CrossRef] [PubMed]

38. Woo, P.C.Y.; Lau, S.K.P.; Li, K.S.M.; Poon, R.W.S.; Wong, B.H.L.; Tsoi, H.; Yip, B.C.K.; Huang, Y.; Chan, K.; Yuen, K. Molecular diversity of coronaviruses in bats. Virology 2006, 351, 180-187. [CrossRef] [PubMed]

39. Lau, S.K.P.; Woo, P.C.Y.; Li, K.S.M.; Huang, Y.; Wang, M.; Lam, C.S.F.; Xu, H.; Guo, R.; Chan, K.-H.; Zheng, B.-J.; et al. Complete genome sequence of bat coronavirus HKU2 from Chinese horseshoe bats revealed a much smaller spike gene with a different evolutionary lineage from the rest of the genome. Virology 2007, 367, 428-439. [CrossRef] [PubMed]

40. Tang, X.C.; Zhang, J.X.; Zhang, S.Y.; Wang, P.; Fan, X.H.; Li, L.F.; Li, G.; Dong, B.Q.; Liu, W.; Cheung, C.L.; et al. Prevalence and genetic diversity of coronaviruses in bats from China. J. Virol. 2006, 80, 7481-7490. [CrossRef] [PubMed]

41. De Benedictis, P.; Marciano, S.; Scaravelli, D.; Priori, P.; Zecchin, B.; Capua, I.; Monne, I.; Cattoli, G. Alpha and lineage $\mathrm{C}$ betaCoV infections in Italian bats. Virus Genes 2013, 48, 366-371. [CrossRef] [PubMed]

42. Corman, V.M.; Baldwin, H.J.; Fumie Tateno, A.; Melim Zerbinati, R.; Annan, A.; Owusu, M.; Nkrumah, E.E.; Maganga, G.D.; Oppong, S.; Adu-Sarkodie, Y.; et al. Evidence for an ancestral association of human coronavirus 229E with bats. J. Virol. 2015, 89, 11858-11870. [CrossRef] [PubMed]

43. Demanche, C.; Deville, M.; Michaux, J.; Barriel, V.; Pinçon, C.; Aliouat-Denis, C.M.; Pottier, M.; Noël, C.; Viscogliosi, E.; Aliouat, E.M.; et al. What do Pneumocystis organisms tell us about the phylogeography of their hosts? The case of the woodmouse Apodemus sylvaticus in continental Europe and western Mediterranean islands. PLoS ONE 2015, 10, e0120839. [CrossRef] [PubMed]

44. Realpe, T.; Correa, N.; Rozo, J.C.; Ferro, B.E.; Gomez, V.; Zapata, E.; Ribon, W.; Puerto, G.; Castro, C.; Nieto, L.M.; et al. Population structure among mycobacterium tuberculosis isolates from pulmonary tuberculosis patients in Colombia. PLoS ONE 2014, 9, e93848. [CrossRef] [PubMed]

45. Cox, C.B. Plate tectonics, seaways and climate in the historical biogeography of mammals. Mem. Inst. Oswaldo Cruz 2000, 95, 509-516. [CrossRef] [PubMed]

46. Carrington, C.V.F.; Foster, J.E.; Zhu, H.C.; Zhang, J.X.; Smith, G.J.D.; Thompson, N.; Auguste, A.J.; Ramkissoon, V.; Adesiyun, A.A.; Guan, Y. Detection and phylogenetic analysis of group 1 coronaviruses in South American bats. Emerg. Infect. Dis. 2008, 14, 1890-1893. [CrossRef] [PubMed]

47. Wacharapluesadee, S.; Duengkae, P.; Rodpan, A.; Kaewpom, T.; Maneeorn, P.; Kanchanasaka, B.; Yingsakmongkon, S.; Sittidetboripat, N.; Chareesaen, C.; Khlangsap, N.; et al. Diversity of coronavirus in bats from Eastern Thailand. Virol. J. 2015, 12, 57. [CrossRef] [PubMed]

(C) 2015 by the authors; licensee MDPI, Basel, Switzerland. This article is an open access article distributed under the terms and conditions of the Creative Commons by Attribution (CC-BY) license (http:/ / creativecommons.org/licenses/by/4.0/). 